\title{
Distribution of copper in soil and rice system of Hainan Island, China
}

\author{
WANG Dengfeng ${ }^{1, \dagger},{ }^{*}$, HUANG Haijie ${ }^{1, \dagger}$, FENG Huande ${ }^{1}$, WANG Hua ${ }^{2}$, HAN Miaojie ${ }^{1}$ \\ And QI Zhiping . \\ ${ }^{1}$ Tropical Crops Genetic Resources Institute of CATAS, Danzhou 571737, China; ${ }^{2}$ Institute of Spice and Beverage \\ Research, CATAS, Wanning 571533, China; ${ }^{\dagger}$ The authors who contributed equally to this study.
}

\begin{abstract}
This research aimed to discover the distribution and the primary influence factors of Cu in the soil-rice systems of tropical farmland. Soil samples of farmland and rice plant (stalk and polished rice) from the western region of Hainan Island were collected and studied. The results showed that the average Cu content in the topsoil of the study area was $15.75 \mathrm{mg} \mathrm{kg}^{-1}$; the highest $\mathrm{Cu}$ content (45.92 $\mathrm{mg} \mathrm{kg}^{-1}$ ) was found in the rice fields of the northern area, where pyroclastic parent material is distributed. Thus, there is a potential for $C u$ contamination of the rice grown in this region. The average contents of $\mathrm{Cu}$ in the rice stalks and polished rice were 16.9 and $5.68 \mathrm{mg} \mathrm{kg}^{-1}$, respectively, indicating that the stalks had a larger capacity for $\mathrm{Cu}$ bioaccumulation than the polished rice. The bioaccumulation factor $(B A F)$ of $\mathrm{Cu}$ in rice was found to decrease with increased $\mathrm{Cu}$ contents in the soil. In regards to the northern farmlands with high $\mathrm{Cu}$ contents in the soil derived from pyroclastic deposits, an alkaline fertilizer should be used to prevent the risk of $\mathrm{Cu}$ pollution in the polished rice, as soil acidification can promote the uptake and accumulation of $\mathrm{Cu}$ to some extent.
\end{abstract}

Key words: rice; copper; arable land; Hainan

\footnotetext{
*Authors for correspondence: dfwang@vip.163.com
} 


\section{INTRODUCTION}

Heavy metal pollution control is gaining attention, as heavy metal pollution in farmland is becoming an increasingly dire issue (Chen et al., 2011; Xin et al., 2011). In recent years, nearly one fifth of China's farmland has faced heavy metal pollution to some extent, resulting in a drop of more than 10 million tons in the annual food grain output (Zhao, 2004). Copper $(\mathrm{Cu})$ is necessary for the normal growth of plants and animals, but excessive $\mathrm{Cu}$ can be harmful (Alloway, 1990; Chen, 1996; Wang et al., 2005). Moderate amounts of $\mathrm{Cu}$ in the human body are beneficial and even have anticancer properties, but high levels can be harmful (Kabata Pendias and Pendias, 2001; Xia and Lu, 2011).

Because rice is a staple food throughout the world, its $\mathrm{Cu}$ content has a significant effect on the $\mathrm{Cu}$ intake by human being. Thus, the content distribution of $\mathrm{Cu}$ in soil-rice systems is a concern to the academic community (Zhao et al., 2012; Zheng et al., 2005). Rice is a main food crop grown on Hainan Island. In 2011, rice fields made up 74 percent of the island's total food-growing land area (SBHP and SONBSH, 2012), which means the rice's $\mathrm{Cu}$ content has a large bearing on the $\mathrm{Cu}$ intake of local residents. Previous research projects focused on heavy metal distributions in the soil and ecological risk assessments of some regions of the island (Geng et al., 2012; Tan et al., 2011; Wang et al., 2013), but few studies have investigated the distribution of $\mathrm{Cu}$ in the soil-rice systems. Therefore, this research examined the distribution and primary factors influencing $\mathrm{Cu}$ in the soil-rice system of the island's western agricultural area. Soil and rice samples collected from this region were studied with spatial analysis techniques. The results of this research can provide a basis for further investigation of the distributions of $\mathrm{Cu}$ and other trace elements in soil-rice systems.

\section{MATERIALS AND METHODS}

\section{Study area}

The study area included four counties in the western region of Hainan: Danzhou, Baisha, Changjiang, and Dongfang, covering approximately $13300 \mathrm{~km}^{2}$. This area has a tropical monsoon climate with an average annual temperature of $22-26^{\circ} \mathrm{C}$ and average annual rainfall of $1150-1815 \mathrm{~mm}$. The northwestern study areawas lower in elevation than the southeastern hills and mountainous terrains. In the southeastern part, the primary parent material was residual clastic sediments, covering $12 \%$ of the study area. In the western coastal region, the soil was formed from marine sediments, making up $17 \%$ of the soil. In the northern region and the central plains area, the soils were derived from pyroclastic deposits (2\%) and residual acid igneous rocks (45\%), respectively. Fluvial (5\%) and acid metamorphic $(7 \%)$ parent materials were also scattered in study area (Figure 1).

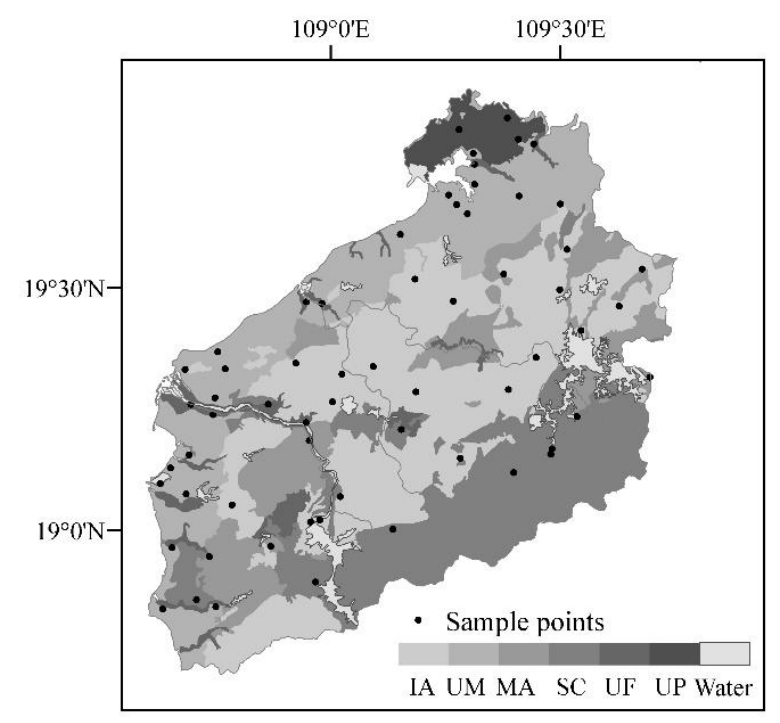

Figure 1 - Distribution of soil parent materials and sample points in the study área.

IA: acid igneous, MA: acid metaprophic, SC: clastic sediments, UF: fluvial, UM: marine, UP: pyroclastic, Water: river and lakes.

\section{Sampling and analyses}

A total of 63 top soil samples were collected from upper $20 \mathrm{~cm}$ in study area. Each sample weighed 2 $\mathrm{kg}$, and was obtained by quartering a mixture of the soils from 5-10 sampling points. A total of 126 rice samples, including 63 groups of rice stalks and grains, were collected from 10-15 rice plants around the soil sampling points. And the samples were collected at the rice harvest season, since it is the best stage to represent contents distribution of $\mathrm{Cu}$ in rice grain and stalk.

After being air-dried at room temperature, the soil samples were crashed and sifted through a nylon sieve $(2 \mathrm{~mm})$ for soil $\mathrm{pH}$ and cation exchange capacity (CEC) analysis. Then, they were sifted 
through two additional nylon sieves $(0.25 \mathrm{~mm}$ and $0.149 \mathrm{~mm}$ ) to measure the contents of organic matters and total $\mathrm{Cu}$ in soil. The rice samples, after being washed with deionized water, were treated for $30 \mathrm{~min}$ for deactivation of enzymes at $105^{\circ} \mathrm{C}$ and then dried at $75^{\circ} \mathrm{C}$ for one week. The rice grains were threshed by hand and then decorticated and processed by machine to obtain the polished rice. Finally, the stalks and polished rice grains were crushed and sifted through a nylon sieve $(0.149 \mathrm{~mm})$ for the measurement of $\mathrm{Cu}$ content.

To measure the soil $\mathrm{pH}$ using glass electrode, the soil samples were mixed with water at a ratio of 5:1 (w/v). After oxidized by $\mathrm{K}_{2} \mathrm{Cr}_{2} \mathrm{O}_{7}$, the concentration of organic matters in soil was measured by the titration method. The CEC was determined by the Kjeldahl distillation and titration method, after extracted with $\mathrm{NH}_{4} \mathrm{OAc}$. Then, after heating and digesting the soil and rice samples with $\mathrm{HClO}_{4}$ and $\mathrm{HNO}_{3}$, an analysis of the total $\mathrm{Cu}$ amount was conducted using an inductively coupled plasma-atomic emission spectrometer (ICP-AES) (Lu, 2000).

\section{Statistical analyses}

All statistical analyses were performed using SAS 9.0. Analysis of variance was used to assess significant differences between different parameters, the confidence interval for the Student t-test was calculated at $\alpha=0.05$. The distribution of sampling points and soil $\mathrm{Cu}$ content were plotted using the spatial analysis function of ArcGIS 10.0, and the scatter plots were presented with Excel 2007.

The bioaccumulation factor (BAF) of trace elements in plants, the ratio of trace elements contents in plants to soil, can indicate the accumulation ability of trace element of plants. In this study, the BAF of $\mathrm{Cu}$ in rice plant was calculated by equation 1 :

$\mathrm{BAF}_{\mathrm{Cu} \text { in rice }}=C_{\text {rice }} / C_{\text {soil }}$ (1)

Where, $C_{\text {rice }}$ and $C_{\text {soil }}$ were $\mathrm{Cu}$ concentration in rice plant and soil, respectively.

\section{RESULTS AND DISCUSSION}

\section{Soil properties and Content of $\mathrm{Cu}$ in soil}

The soils had weak acidic conditions in study area (Table 1), with soil $\mathrm{pH}$ ranging from 4.79 to 8.34 , and the average soil $\mathrm{pH}$ 6.06. The content of organic matters in soil of research area was 30.62 $\mathrm{g} \mathrm{kg}^{-1}$. The CEC was $15.2 \mathrm{cmol}_{\mathrm{c}} \mathrm{kg}^{-1}$ and varied from 5.3 to $30.0 \mathrm{cmol}_{\mathrm{c}} \mathrm{kg}^{-1}$ (Wang et al., 2014).

Table 1 - Statistical summary of soil properties

\begin{tabular}{llllll}
\hline & Min & Max & $\begin{array}{l}\text { Media } \\
n\end{array}$ & $\begin{array}{l}\text { AM } \pm \text { ASD } \\
\text { c mean }\end{array}$ \\
\hline pH & 4.79 & 8.34 & 5.81 & $6.06 \pm 0.87$ & 6.01 \\
Organi & & & & & \\
$\mathrm{c}$ & 13.2 & 60.5 & 30.17 & $30.62 \pm 8.5$ & 29.58 \\
$\begin{array}{l}\text { matters } 7 \\
\left(\mathrm{~g} \mathrm{~kg}^{-1}\right)\end{array}$ & 1 & & & & \\
$\begin{array}{l}\mathrm{CEC}^{\left(\mathrm{cmol}_{\mathrm{c}}\right.} \\
\left.\mathrm{kg}^{-1}\right)\end{array}$ & 5.3 & 30.0 & 15.2 & $15.2 \pm 5.5$ & 14.2 \\
\end{tabular}

AM \pm ASD: Arithmetic mean \pm arithmetic standard deviation

The content of $\mathrm{Cu}$ in the topsoil of the study area ranged from 2.82 to $49.73 \mathrm{mg} \mathrm{kg}^{-1}$ with an average of $15.75 \mathrm{mg} \mathrm{kg}^{-1}$ (Table 2). The relatively low content of $\mathrm{Cu}$ in the soil suggested a small ecological risk. The content of $\mathrm{Cu}$ in the topsoil varied depending on the type of parent material, and its spatial distribution was determined by the distribution of parent materials. In the study area, the soil derived from pyroclastic sediments had the highest content of $\mathrm{Cu}$ at $45.92 \mathrm{mg} \mathrm{kg}^{-1}$, compared to 13.24 and $11.29 \mathrm{mg} \mathrm{kg}^{-1}$ in the soils derived from clastic sediments and fluvial deposits, respectively. The $\mathrm{Cu}$ contents were all lower than $10 \mathrm{mg} \mathrm{kg}^{-1}$ in the soils derived from residual acid igneous, metamorphic rocks and marine sediments. In terms of spatial distribution, the soils with high $\mathrm{Cu}$ contents were mainly distributed in the northern area of Danzhou and the southern region of Baisha (Figure 2). The distribution of $\mathrm{Cu}$ content in the topsoil showed a similarity to the distribution of parent materials, demonstrating that the former was closely associated with the latter. Alloway (1990), Lu et al. (2012) and Wang et al. (2013) also concluded that the parent material was one of main factors influencing heavy metal concentrations in soil. 
Table 2 - Concentrations distribution of $\mathrm{Cu}$ in soil of study area

\begin{tabular}{|c|c|c|c|c|c|}
\hline \multirow{2}{*}{$\begin{array}{l}\text { Parent } \\
\text { materials }\end{array}$} & \multirow[t]{2}{*}{$\mathrm{N}$} & Range & $\begin{array}{l}\text { Med } \\
\text { ian }\end{array}$ & $\begin{array}{l}\mathrm{AM} \pm \mathrm{A} \\
\mathrm{SD}^{\dagger}\end{array}$ & \multirow{2}{*}{$\begin{array}{l}\mathrm{C} \\
\mathrm{V}^{*} \\
\%\end{array}$} \\
\hline & & $\mathrm{mg} \mathrm{kg}^{-1}$ & & & \\
\hline $\begin{array}{l}\text { Acid } \\
\text { igneous }\end{array}$ & $\begin{array}{l}2 \\
0\end{array}$ & $\begin{array}{l}2.82- \\
18.23\end{array}$ & 5.13 & $\begin{array}{l}6.18 \pm 4 \\
23 \mathrm{bc}\end{array}$ & $\begin{array}{l}68 \\
.4\end{array}$ \\
\hline $\begin{array}{l}\text { Acid } \\
\text { metaproph } \\
\text { ic }\end{array}$ & 5 & $\begin{array}{l}4.15- \\
12.50\end{array}$ & 7.44 & $\begin{array}{l}7.88 \pm 3 \\
73 \mathrm{bc}\end{array}$ & $\begin{array}{l}47 \\
.3\end{array}$ \\
\hline $\begin{array}{l}\text { Clastic } \\
\text { sediments }\end{array}$ & 8 & $\begin{array}{l}6.41- \\
19.65\end{array}$ & $\begin{array}{l}12.9 \\
2\end{array}$ & $\begin{array}{l}13.24 \pm 4 \\
.88 \mathrm{~b}\end{array}$ & $\begin{array}{l}36 \\
.9\end{array}$ \\
\hline Fluvial & 7 & $\begin{array}{l}7.62- \\
17.21\end{array}$ & $\begin{array}{l}11.3 \\
9\end{array}$ & $\begin{array}{l}11.29 \pm 3 \\
.50 \mathrm{~b}\end{array}$ & $\begin{array}{l}31 \\
.0\end{array}$ \\
\hline Marine & $\begin{array}{l}2 \\
0\end{array}$ & $\begin{array}{l}1.94- \\
14.88\end{array}$ & 7.00 & $\begin{array}{l}7.87 \pm 4 \\
11 \mathrm{bc}\end{array}$ & $\begin{array}{l}52 \\
.2\end{array}$ \\
\hline Pyroclastic & 3 & $\begin{array}{l}35.56- \\
49.73\end{array}$ & $\begin{array}{l}42.1 \\
1\end{array}$ & $\begin{array}{l}45.92 \pm 5 \\
.39 \mathrm{a}\end{array}$ & $\begin{array}{l}11 \\
.7\end{array}$ \\
\hline Total & $\begin{array}{l}6 \\
3\end{array}$ & $\begin{array}{l}2.82- \\
49.73\end{array}$ & 7.31 & $\begin{array}{l}15.75 \pm 9 \\
.10\end{array}$ & $\begin{array}{l}57 \\
.8\end{array}$ \\
\hline
\end{tabular}

${ }^{\dagger} \mathrm{AM} \pm$ ASD: Arithmetic mean \pm arithmetic standard deviation, values with different superscripts in a column differ significantly $(\mathrm{P}<0.05)$. ${ }^{\mathrm{C}} \mathrm{CV}$ : Coefficient of variation.

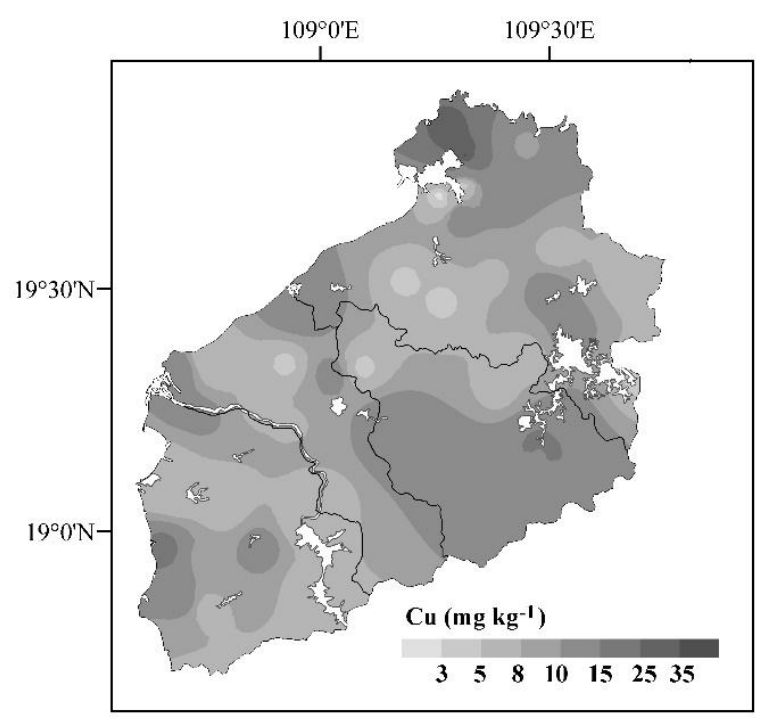

Figure 2 - Spatial distribution of $\mathrm{Cu}$ in soil of study area

\section{Content of $\mathrm{Cu}$ in the rice}

The content of $\mathrm{Cu}$ in the rice stalks ranged from 10.79 to $23.65 \mathrm{mg} \mathrm{kg}^{-1}$, with an average of 16.85 $\mathrm{mg} \mathrm{kg}^{-1}$; and the $\mathrm{Cu}$ content in the polished rice was in the range of 3.65 to $8.43 \mathrm{mg} \mathrm{kg}^{-1}$, with an average of $5.68 \mathrm{mg} \mathrm{kg}^{-1}$, which was much lower than that in the rice stalks (Table 3). This difference demonstrated that the element $\mathrm{Cu}$ was more likely to accumulate in rice stalks, consistent with previous research findings (Kang and Xie, 2006). In order to maintain the $\mathrm{Cu}$ homeostasis in young leaves, the transport of $\mathrm{Cu}$ via xylem to mature leaves was be inhabit while the transport via phloem to young leaves was promoted (Ando et al., 2013; Zheng et al., 2012). Zheng et al. (2012) also indicated that $\mathrm{Cu}$ was more tend to be accumulated in flag leaf and husk than rice grain in the reproductive stage of rice plant.

The content and distribution of $\mathrm{Cu}$ in the rice was not only influenced by the self-regulatory mechanism of the plant, but also by the concentration of $\mathrm{Cu}$ in the soil. The results revealed that the $\mathrm{Cu}$ content was more in the rice stalks and grains with increased $\mathrm{Cu}$ content in the soil. However, the $\mathrm{BAF}$ of $\mathrm{Cu}$ in rice plant, the ratio of $\mathrm{Cu}$ concentration in rice plant to soil, was found to gradually decrease with an increasing $\mathrm{Cu}$ concentration in soil (Figure 3), indicating that an increase in the $\mathrm{Cu}$ content in the soil reduced the plant's capacity for $\mathrm{Cu}$ bioaccumulation. This may be attributed to the $\mathrm{Cu}$ saturation in the rice and the down regulation of the plant (Zhao et al., 2003). Thounaojam et al. (2012) indicated that doxidative stress of rice plants were induced as $\mathrm{Cu}$ concentration in soil elevated, while the stimulated anti-oxidative system of rice, which generate antioxidant enzymes, can set off against $\mathrm{Cu}$ induced oxidative stress and inhabit the accumulation of $\mathrm{Cu}$ in rice stalks and grains. Therefore, it follows that high $\mathrm{Cu}$ contents in soils derived from pyroclastic parent material do not pose a risk of $\mathrm{Cu}$ contamination in polished rice due to the rice's self-regulatory mechanism.

Table 3 - Contents distribution of $\mathrm{Cu}$ in rice plants

\begin{tabular}{|c|c|c|c|c|}
\hline & Range & $\begin{array}{l}\text { Medi } \\
\text { an }\end{array}$ & $\begin{array}{l}\mathrm{AM} \pm \mathrm{AS} \\
\mathrm{D}^{\dagger}\end{array}$ & \multirow{2}{*}{$\begin{array}{l}\mathrm{C} \\
\mathrm{V}^{\ddagger} \\
\%\end{array}$} \\
\hline & $\mathrm{mg} \mathrm{kg}^{-1}$ & & & \\
\hline $\begin{array}{l}\text { Polished } \\
\text { rice }\end{array}$ & $\begin{array}{l}3.65- \\
8.43\end{array}$ & 5.39 & $\begin{array}{l}5.68 \pm 1.28 \\
\text { b }\end{array}$ & $\begin{array}{l}22 . \\
5\end{array}$ \\
\hline Stalk & $\begin{array}{l}10.79- \\
23.65\end{array}$ & 16.80 & $\begin{array}{l}16.85 \pm 2.8 \\
8 \mathrm{a}\end{array}$ & $\begin{array}{l}17 . \\
1\end{array}$ \\
\hline
\end{tabular}

AM \pm ASD: Arithmetic mean \pm arithmetic standard deviation, values with different superscripts in a column differ significantly $(\mathrm{P}<0.05)$. ${ }^{\mathrm{C}} \mathrm{CV}$ : Coefficient of variation. 


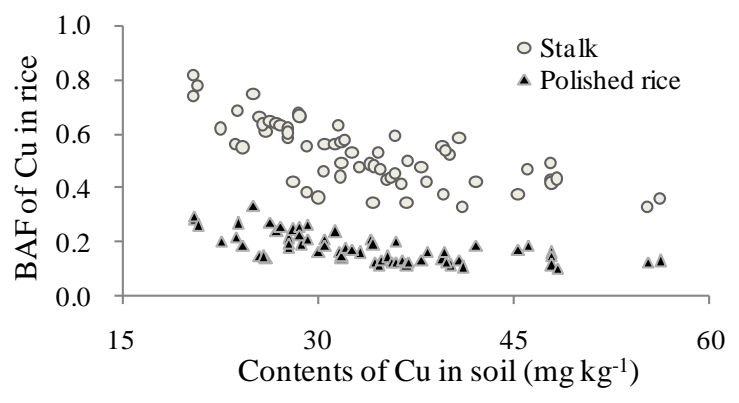

Figure 3 - Relationship between the $\mathrm{BAF}$ of $\mathrm{Cu}$ in rice and $\mathrm{Cu}$ content in soil

The gradual $\mathrm{pH}$ decrease in China's farmland soil in recent years demonstrates severe soil acidification (Guo et al., 2010), which greatly impacts the biological availability of certain trace elements in the soil. Since the second national soil survey was conducted in the 1980s, Hainan's farmland has faced serious soil acidification (Wei et al., 2013). Due to the $\mathrm{Cu}$ absorbing capability of soil minerals from soil solution was determined by the surface charge carried by adsorbents, and the surface charge was mainly controlled by soil $\mathrm{pH}$, the soil acidification level was one of the most important influence factors to availability of $\mathrm{Cu}$ in soil (Kabata Pendias and Pendias, 2001). Studenikina (1999) also indicated that the binding of $\mathrm{Cu}$ by soil was highly dependent on soil $\mathrm{pH}$. Therefore, it was necessary to analyze the influence of the soil $\mathrm{pH}$ on the bioaccumulation of $\mathrm{Cu}$ in polished rice. The results showed that the decrease in soil $\mathrm{pH}$ promoted the bioaccumulation of $\mathrm{Cu}$ in the polished rice, indicating that soil acidification enhanced the $\mathrm{Cu}$ bioaccumulation capacity of the polished rice to some degree (Figure 4). For this reason, farmland with high $\mathrm{Cu}$ contents in soil formed from pyroclastic deposits should be properly treated with alkaline fertilizer to avoid excessive $\mathrm{Cu}$ bioaccumulation in polished rice due to soil acidification.

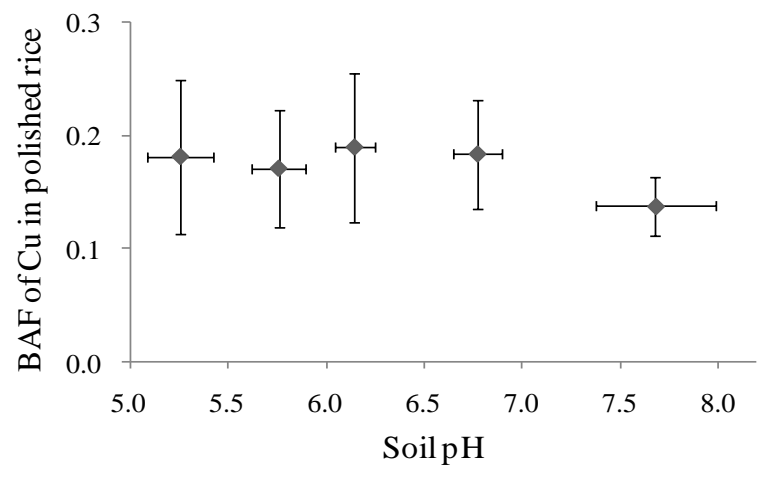

Figure 4 -Relationship between the BAF of $\mathrm{Cu}$ in polished rice and soil $\mathrm{pH}$

\section{CONCLUSION}

In the western region of Hainan Island, the overall $\mathrm{Cu}$ content in the farmland topsoil was generally low although unevenlydistributed. The highest $\mathrm{Cu}$ content, found in the northern area where the topsoil was derived from pyroclastic parent material, was measured at $42.47 \mathrm{mg} \mathrm{kg}^{-1}$. The results of the study revealed that the use of chemical fertilizers and pesticides, together with a high multiple cropping index, increased the $\mathrm{Cu}$ bioaccumulation in the rice, posing a potential risk of $\mathrm{Cu}$ contamination. The rice stalks showed a greater capacity for $\mathrm{Cu}$ bioaccumulation than the polished rice. It was also discovered that the $\mathrm{Cu}$ bioaccumulation factor of the rice (including stalks and grains) decreased with higher levels of $\mathrm{Cu}$ in the soil. In addition, soil acidification was found to promote the $\mathrm{Cu}$ bioaccumulation in the polished rice to some degree. Therefore, farmland soil derived from pyroclastic deposits with high $\mathrm{Cu}$ contents should be properly treated with alkaline fertilizer to avoid the potential risk of $\mathrm{Cu}$ contamination in polished rice that is posed by soil acidification.

\section{ACKNOWLEDGMENTS}

Anonymousreviewers are appreciated for their comments on this study. This research was supported by The National Natural Science Foundation of China (41501225) and National Nonprofit Institute Research Grant of CATASTCGRI (1630032014035).

\section{REFERENCES}

Alloway B.J.,Heavy metals in soils. John Wiley \& Sons, Inc., New York, 1990

Ando Y., Nagata S., Yanagisawa S., Yoneyama T.,Copper in xylem and phloem saps from rice (Oryza sativa):the effect of moderate copper concentrations in the growthmedium on the accumulation of five essential metals anda speciation analysis of copper-containing compounds. Funct. Plant Biol., 2012, 40, 89-100

Chen H.M.,Heavymetal pollution in the soil and plant system. Science Press, Beijing, 1996

Chen Y.J., Xiao B.L., Fang L.N., Ma H.L., Yang R.Z., Li X.Y., et al.,The quality analysis of cultivated land in China. Sci. Agric. Sinica,2011, 44, 35573564 
Geng J.M., Wang W.B., Wen C.P., Yi Z.Y., Tang S.M., Concentrations and distributions of selenium and heavy metals in Hainan paddy soil and assessment of ecological security. Acta Ecol. Sinica, 2012, 32, 3477-3486

Guo J.H., Liu X.J., Zhang Y., Shen J.L.,Han W.X., Zhang W.F., et al., Significant acidification in major Chinese croplands. Science, 2010, 327, 1008-1010

KabataPendias A., Pendias H,Trace Elements in Soils and Plants. CRC Press, Washington, 2001

Kang L.J., Xie Z.L.,Contrastive study of pollution effect and accumulative rules of copper on corn and rice. J Jilin Agr. Univ., 2006, 28, 656-659

Lu A.X., Wang J.H.,Qin X.Y.,Wang K.Y., Han P.,Zhang S.Z., Multivariate and geostatistical analyses of the spatial distribution and origin of heavy metals in the agricultural soils in Shunyi, Beijing, China. Sci. Total Environ., 2012, 425, 6674

Lu R.K., Analysis methods of soil agricultural chemistry. China Agricultural Science Press, Beijing,2000

SBHP (Statistical Bureau of Hainan Province), SONBSH (Survey Office of National Bureau of Statistics in Hainan), Hainan statistical yearbook. China Statistics Press, Beijing, 2012

Studenikina T.A., Interaction of copper (II) with soil components under influence of organic matter dissolved in soil solution. Ph.D. thesis, Moscow University, Russia, 1999

Tan Y.H., Wei J.H., Chen Z., Gao W.W,Distribution and evaluation of heavy metal contents in the soil of areca catechu plantations in Hainan. China Environ. Sci., 2011, 31, 815-819

Thounaojam T.C.,Panda P., Mazumdar P., Kumar D., Sharma G.D., Shaoo L., et al., Excess copper induced oxidative stress and response of antioxidants in rice. Plant Physiol. Bioch., 2012, 53, 33-39

Wang D.F., Wei Z.Y., Han M.J., Qi Z.P.,Distribution characteristics of zinc in arable land soil of northwestern Hainan. J. South. Agr., 2013, 44, 447-451

Wang D.F., Wei Z.Y., Tang S.M., Qi Z.P., Distribution of selenium and cadmium in soil-rice system of selenium-rich area in Hainan, China. Pak. J. Pharm. Sci., 2014, 27, 1633-1639

Wang H.B., Shu W.S., Lan C.Y.,Ecology for heavy metal pollution: recent advances and future prospects. Acta Ecol. Sinica, 2005, 5, 596-605

Wei J.Z., Wang D.F., Wei Z.Y., Qi Z.P.,Temporal and spatial distribution of soil $\mathrm{pH}$ in arable land of Changjiang, Hainan. Chin. J. Trop. Crops, 2013, 34, 413-417

Xin S.Z., Li H.F., Su D.C.,Concentration characteristics and historical changes of heavy metals in irrigation sewage in China. J. Agro-Environ. Sci., 2011, 30, 2271-2278

Xia S.F.,Lu X.M.,Progress of anticancer activities of copper complexes with 1,10-phenanthroline and its derivatives. Chem., 2011, 74, 1096-1104

Zhao F.J.,Lombi E., McGrath S.P.,Assessing the potential for zinc and cadmium phytoremediation with the hyperaccumulator Thlaspi caerulescens. PlantSoil, 2003,249,37-43

Zhao J.N, Wang Y.X., Shen C.X., Yang L.X., Wang Y.L., Effect of soil copper contamination on rice yield formation: A 5-year located experiment. J. Agro-Environ. Sci., 2012 31, 2073-2081

Zhao Q.G.,Land resources, mother earth-protection, construction and sustainable utilization of the land resources of China, issues that deserve high attention. Soil, 2004, 36, 337-339

Zheng L.Q., Yamaji N., Yokosho K., Ma J.F., YSL16 is a phloem-localized transporter of the coppernicotianamine complex that is responsible for copper distribution in rice. Plant Cell, 2012, 24, 3767-3782

Zheng Y.M., Chen T.B., Zheng G.D., Chen H., Luo J.F., Wu H.T., et al.,Soil copper accumulation under different land use types: The case of Beijing. J. Nat. Resour., 2005, 20, 690-696

Received: June 15, 2016; Accepted: June24, 2016 